\title{
TCOM \\ Individual solutions to collective problems: the paradoxical treatment of environmental issues on Mexican and French YouTubers' videos
}

\section{Cecilia Lartigue, Guillaume Carbou and Muriel Lefebvre}

\begin{abstract}
The impact of human activity on our planet is undeniable. However, this matter of fact is not fully understandable without analyzing the narratives through which people make sense of it. In this study, we aim to describe the narratives present in environmental discourses of Mexican and French YouTubers' videos. This corpus is intended to show how environmental issues are framed in the ever-growing discursive arena of entertainment and "influencing" streaming video. We set out to perform a cross-country comparison, with the purpose of contributing to the discussion of whether environmental discourse is country-specific or shared by various nations and, possibly, even global. Our study contributes to the understanding of the social construction of the environment via these discourses. Our main result points to a paradoxical treatment of environmental issues: the YouTubers of our sample represent them as collectively induced problems, but seem to mainly believe that individual-based solutions would resolve them. More broadly, our study suggests a tendency to the individualization and, therefore, the depoliticization of environmental issues as well as a globalization of the environmental discourses in YouTubers' videos.
\end{abstract}

Keywords

DOI

Environmental communication; Public understanding of science and technology; Science communication in the developing world

https://doi.org/10.22323/2.20070207

Submitted: 31st March 2021

Accepted: 27th October 2021

Published: 9th December 2021

Introduction

Some scientists believe that we are living in a new geological era, which they have named "Anthropocene", with the argument that human activity has altered our planet so profoundly that it has become a geological force [Bonneuil, 2019]. For instance, beyond the well-known human-induced increase of carbon dioxide concentration in the atmosphere or the major decrease of biodiversity, other geological indicators confirm the deep "terraforming" role of contemporary humanity: the worldwide presence of microplastics, the spread of radionuclides from nuclear testing, as well as the levels of phosphate and nitrate in the Earth's 
crust [Canabate, 2019]. On a planetary level, the melting of ice caps at the poles cause a decrease of pressure, which has led to a significant change in volcanic eruptions worldwide [Bonneuil, 2019]. All these phenomena may be considered objective evidence that we have indeed entered the "Anthropocene era". However, this classification of the human relationship with the environment is not only a matter of material facts but also involves the narratives that make sense of them. Indeed, in a constructivist approach [Berger and Luckmann, 1966], both the environment and environmental problems are socially constructed, given that they are defined through collective processes [Taylor, 2000]. One of these processes is environmental discourse, which contributes to the construction of environmental concern through a narrative pathway [Jalenques-Vigouroux, 2006].

According to Harcourt et al. [2020], societies use narrative as a way to respond to difficult and complicated issues. More generally, the human activity of making sense of concepts is narrative-based. Among other aspects, storytelling allows societies to reflect on potential outcomes before they actually occur. With time, one of these narratives emerges as seeming the most probable. Eventually, through reiteration, this means of framing a topic comes to be seen as the social norm and the preferred way forward on the issue [Bruner, 1991]. By consequence, studying narratives about the environment and environmental crises contributes to understanding the way societies relate to the environment. It is then possible to identify aspects that can be reinforced as well as new elements that could be introduced in communication efforts, for the sake of environmental protection. According to Kelly, Cooley and Klinger [2014] narrative analysis "can motivate responsive environmental policy, effectively improving social feedback to natural systems".

This study aims to contribute to the study of current environmental discourse by comparing a sample of French and Mexican YouTubers' videos that address different environmental problems. Our presumption was that this comparison could provide insights into whether environmental discourse on transnational web platforms such as YouTube is globalized or not, given the significant differences between both countries in terms of their history, geopolitical role, socio-demographics, and environmental conditions. Indeed, our study shows that, in spite of these discrepancies, discourses of YouTubers of our sample from both nations are similar, suggesting a globalization of environmental discourse in these kinds of videos.

Moreover, we performed a narrative analysis adapted from Greimas' actantial model (1966) in order to identify the actors present in environmental narratives, and the role they are supposed to play. As we will point out further on, this analysis shows that the prevalent narrative in our corpus can be considered as quite paradoxical. Indeed, in our corpus, YouTubers mainly designate collective agents (humanity, governments, lobbies, etc.) as being responsible for environmental harm, but only suggest individual actions to resolve the situation. Before addressing this observation, we will now present our theoretical and methodological background. 
One of the current leading environmental narratives, particularly prevalent in documents related to climate change, includes the idea that scientists have recently alerted the world (late 20th century) to the impact of human beings on the environment on a global scale. This narrative has been called "modern reflexivity" by the historian Bonneuil [2019]. In his studies, he challenges this narrative by showing that past societies were also ecologically conscious. For example, that, already in the nineteenth century, theories already existed regarding the connection between climate and deforestation used by Europeans to try to modify the weather.

It is difficult to precisely define the exact moment when well-developed discourses concerning the danger represented by human action on the environment appeared [Harré, Brockmeier and Mühlhäusler, 1999]. According to Bourg and Papaux [2015], they came into being in the nineteenth century and became a distinguishable current of thought during the second half of the twentieth century. They were initially characterized by skepticism relating to the promises of technology to create a better world for everyone and romantic or conservative criticism of industrialization and of the pollution, poverty and standardization associated with it [Audier, 2019]. In contrast, in the 1980s, a positive perception of technology with regard to the environment emerged along with the notion of ecological modernization. It mainly frames the resolution of environmental problems that come to the fore in this decade as a question of radical innovation in clean technology that would lead to an improvement in environmental management [Rutherford, 1999].

Current research on prevailing narratives in contemporary environmental discourses identifies several recurring patterns. Among them, we can find the following: (1) the global perception of environmental problems: people perceive that there is a single big environmental problem, instead of numerous local or regional ones [Harré, Brockmeier and Mühlhäusler, 1999]. (2) The attribution of responsibility for environmental problems: the "Anthropocene" discourse attributes it to humankind as a whole [Canabate, 2019]. In return, capitalocene, thermocene, plantationocene, among other discourses, challenge the afore-mentioned idea. Instead, they attribute the responsibility of environmental harm to specific organizations or activities, capitalism, discovery and the use of fossil fuels, colonialism and organized slave work, etc. These narratives challenge each other in the public space and can be supported by groups with varying areas of interest because of the responsibility and the solutions each suggest. On the subject of responsibility, another common discursive phenomenon is (3) the individualization of environmental problem, and hence their depoliticization [Comby, 2017]. This tendency consists of trying to create environmental awareness in individuals, and to make them adopt environmentally-friendly practices with the idea that the sum of individual efforts will resolve the problems, instead of attributing the problems to the social organization as a whole, of which individuals are a part. For instance, according to Wiedmann et al. [2020], environmental impact is frequently attributed to consumers, with the argument that their purchasing decisions set a series of production activities in motion which in the end leads to impact on the environment. Yet, another discourse seeks (4) cooperation between the modern conception of economic development and progress with the protection of the environment, mainly via technological innovation and environmental 
regulation. This is the sustainable development discourse. In contrast, the "degrowth" discourse is (5) a criticism of the modern conception of "progress" as it is considered a threat to life itself. The "degrowth" discourse seeks the moral and environmental wellbeing of humanity through a cultural reassessment of people's "fundamental needs" [Rutherford, 1999].

\section{Greimas' actantial model for narrative analysis}

It is possible to study environmental discourse by comparing the structure to that of a story. For instance, Harré, Brockmeier and Mühlhäusler [1999] analyzed the "story of environmental education" in the following way: it starts when humans were hunter-gatherers, living in harmony with nature. Later on, with the appearance of industrial activity, environmental destruction began. Humanity then started "behaving badly" - growing excessively, producing pollution, overexploiting natural resources, etc. Environmental education makes its appearance as a benign character that tries to save the Earth and humanity.

For the purpose of this kind of narrative analysis, it is possible to use Greimas' actantial model (1966), which is based on Propp's 'Morphology of the Folktale' [1928]. Greimas' actantial model distinguishes character and action elements according to their function within the plot. It is used to decompose an action into six facets or actants: (1) the subject (e.g., the prince), who wishes or refuses to interrelate with (2) the object (e.g., the princess). (3) The receiver (for instance, the king) is the one to benefit from the subject obtaining or staying away from the object. Additionally, there is (4) a helper, that assists in the completion of the action and (5) an opponent, who tries to prevent it [Hébert, 2019]. This model is very general and can be used to describe a large diversity of type of discourses.

It has already been used to study narratives present in the media. For instance, Aarva and Pakarinen Tampere [2006] studied health promotion narratives in Finland, while Hartz and Steger [2010] analyzed narratives in the mass media of Germany on the subject both of organizations and their managers. We think this model is relevant for our study because of the focus it places on the actors and the mechanics of the events: we can accurately describe responsibilities, causes, consequences, heroes or villains, helpers and opponents and so on. This approach is particularly suitable to analyze environmental discourses because it highlights how environmental harm is framed and the solutions that are suggested.

\section{Freytag's pyramid}

Gustav Freytag was a German writer of the nineteenth century who was interested in classical Greek tragedy and Shakespearean drama. He designed a pyramid to represent structural patterns of narratives. The first part (exposition) includes information on characters and their circumstances. Then comes the rising action, in which conflicts start occurring. The turning point of the narrative is the climax. At this point, according to the main character's actions, the plot changes direction. As action wanes, events lead to the resolution of the conflict. 
Environmental discourse is present in all kind of media, ranging from television, films, books, newspapers, magazines, and radio, as well as the Internet, Web 2.0, and social media [Luedecke and Boykoff, 2017]. A remarkable case of Web 2.0 is YouTube, which has become the biggest online video platform worldwide [Gautier, 2019; Welbourne and Grant, 2016]. For instance, in 2019, approximately two billion people logged onto this platform monthly [Gautier, 2019].

As part of the Web 2.0, YouTube distributes User Generated Content and this has paved the way for the appearance of the so called "YouTubers". They are either amateurs or professionals who upload videos on a regular basis. YouTube has thus become a platform where an individual can build a personal brand and turn it into a career [Holland, 2017]. Among the millions of YouTubers there are those known as "online celebrities", "digital celebrities" or "social media stars" who reach millions of viewers by broadcasting entertainment videos. Through the creation of their own digital image, they attract the attention of a large number of followers, and exert a strong influence on them [Ladhari, Massa and Skandrani, 2020]. According to Hwang and Zhang [2018], these celebrities are more influential and persuasive than traditional celebrities. They are even called influencers.

YouTube is a popular source for scientific information and other issues, such as technology. While web-based textual information requires high levels of reading to understand, the video format of YouTube is more user-friendly, as well as innovative and creative, using visual and audio channels for transmitting text, images, animations, and films [Allgaier, 2019]. Therefore, science popularization is no longer an activity exclusively reserved to professional communicators or scientists, employed by the main media, but it is also carried out by passionate amateurs [Welbourne and Grant, 2016]. Nevertheless, even when it seems to be a powerful tool for education and scientific and environmental communication [León and Bourk, 2018], this is still currently a very under-researched topic in the context of YouTube [Allgaier, 2019]

This study is part of broader research that aims to compare environmental discourse of Mexican and French YouTubers' videos, in terms of linguistic and non-linguistic elements. Our aim was to carry out a cross-country comparison, with the purpose of contributing to the discussion of whether environmental discourse is country-specific or shared by different nations and, possibly, even on a global scale. Given that France and Mexico differ significantly in terms of their history, geopolitical role and socio-demographics, we considered the comparison might prove enlightening.

Some research has been carried out regarding French and Mexican YouTube videos but, as far as we are able to ascertain, none that involves environmental discourse. For instance, Lybecker et al. [2015] analyzed the subjects addressed in YouTube when talking about the Mexico-U.S. border. Cárdenas, Ballesteros and Jara [2017] investigated the use of social networks, including YouTube, in political campaigns in Mexico, Spain, and Chile; Aranda-Ramírez, Moreno-Meza and Tunal-Santiago [2017] studied the effect of YouTube content on the young people of Mexico city regarding psychological factors, such as identity, perception, and sense of belonging. Also, Alonzo González [2020] addressed the matter of property rights 
and the social media policies of UGC More in relation to our semiotic analysis, Ake-Kob [2020] analyzed YouTube videos posted by Mexican drug trafficking organizations and concluded that they had a purpose which was mainly interactional rather than propagandistic.

Regarding academic works in relation to French YouTube videos, they are more abundant than Mexican ones though none was found concerning environmental discourses. For instance, Lahouati et al. [2020] compared the content of YouTube videos that were either pro or anti-vaccine; Da Silva [2019] analyzed the empowerment of black women in France; Koven and Simões Marques [2015] investigated the portrayal of Portuguese immigrants as non-modern Others; by using a socio-semiotic approach, Heuguet [2020] analyzed technical, semiotic and symbolic mediations that support the commercial valuation of music in YouTube. We therefore think that our study can start to fill a gap in the knowledge of the way environmental discourse circulates in YouTubers' videos. Given that the consumption of this ever-growing discursive production is a very popular activity, notably among young people, and that it is becoming increasingly influential compared to traditional media, we think that insights about how the ecological crisis is framed in this arena are particularly valuable today.

Method

To construct our sample, from November 2018 to June 2019, we carried out a YouTube search in Spanish and French. We looked for words related to the environment (Table 1) and environmental threats (relating to international organizations such as the United Nations Environment Program, World Wildlife Fund, and The Nature Conservancy) including terms such as global warming,

Table 1. List of keywords related to the most important environmental threats, which were searched on YouTube to find French and Mexican videos to build our corpus.

\begin{tabular}{llll}
\hline Threat/subject & Words & Subject & Words \\
\hline General & Ecology & Biodiversity loss & Species loss \\
& Ecological problems & & Species extinction \\
& Ecological crisis & & Biodiversity \\
& Environment & & Danger of extinction \\
& Environmental problems & Invasive species & Invasive species \\
& Environmental crisis & & Exotic species \\
Pollution & Nature & Overpopulation & Overpopulation \\
& Pollution & & Population growth \\
& Pollutants & & Demographic explosion \\
& Air & Deforestation & Deforestation \\
& Water & & Forests \\
& Soil & Dead zones & Dead zones \\
& Garbage & & Ocean problems \\
& Waste & & Sea problems \\
Global warming & Global warming & & Ocean pollution \\
& Climate change & & Marine pollution \\
& Greenhouse gases & Erosion & Soil \\
& Water scarcity & & Soil loss \\
& Water crisis & Erosion \\
& Drought & & \\
\hline
\end{tabular}


pollution, loss of biodiversity, deforestation, overpopulation, soil erosion, invasive species and dead zones. We selected videos of French or Mexican origin, belonging to private individuals (YouTubers) because our intention was to study the discourse of this somewhat new voice in environmental communication, and thus we excluded those uploaded by organizations and institutions. We also performed an Internet search regarding the profiles of the French and Mexican YouTubers of our sample in order to determine their age, sex, place of origin and background.

Additionally, with the purpose of increasing the likelihood of our videos being watched by a relatively high number of viewers, we chose those that belonged to YouTubers' channels which had at least 2000 views. Accordingly, we created a sample of 64 videos (32 French and 32 Mexican). This corpus, while relatively small, presents three major interests. First, it includes most of the videos in which popular French and Mexican YouTubers explicitly talk about environmental issues. While statistical representation isn't the goal of our qualitative study, our corpus is, in any case, a good sample of the type of environmental discourses that can be found on YouTubers' entertainment channels. In order to test this assumption, we carried out a similar search in 2021. We compared the results of the 16 videos ( 9 Mexican and 7 French) obtained with the main results of the present study and did not find relevant differences with regard to the main narratives observed, meaning that adding more videos would probably not add significant precision to our descriptions. Secondly, the 64 videos totalize several millions of views, which means the narratives they use are circulating in the public sphere. Thirdly and finally, the size of our sample allows us to carry out an in-depth analysis which, as stated before, is part of a broader research on YouTubers environmental discourses.

We carried out two types of analysis: first, we identified specific issues concerning the various environmental discourses mentioned in the Introduction (Table 2). Through an exploration of the corpus, we found several aspects that were

Table 2. Issues that were analyzed in the sample of French and Mexican YouTubers' videos addressing environmental problems.

\begin{tabular}{|c|c|c|}
\hline Issue & Description & $\begin{array}{l}\text { Mentioned in at least } \\
10 \% \text { of the sample }\end{array}$ \\
\hline $\begin{array}{l}\text { Perceptions of nature and } \\
\text { environment }\end{array}$ & $\begin{array}{l}\text { General perception of nature and of the } \\
\text { environment, as well as the possibility } \\
\text { of human beings being part of them or } \\
\text { independent from them. }\end{array}$ & Yes \\
\hline Scale of environmental problem & Global/National/Local & Yes \\
\hline $\begin{array}{l}\text { Localisation of environmental } \\
\text { problem }\end{array}$ & $\begin{array}{l}\text { Whether the environmental problems } \\
\text { take place in YouTubers' countries or in } \\
\text { countries other than their own. }\end{array}$ & Yes \\
\hline $\begin{array}{l}\text { Ethical dimension of } \\
\text { environmental problem }\end{array}$ & $\begin{array}{l}\text { If the problem is presented as a } \\
\text { wrongdoing of human beings. }\end{array}$ & Yes \\
\hline Mention of religious elements & $\begin{array}{l}\text { Mention of elements linked to the } \\
\text { Catholic religion (for instance, excerpts } \\
\text { from the Bible) }\end{array}$ & Yes \\
\hline Perception of technology & $\begin{array}{l}\text { Perception of technology in a negative } \\
\text { or positive way }\end{array}$ & No \\
\hline $\begin{array}{l}\text { Critique of capitalist economic } \\
\text { system }\end{array}$ & $\begin{array}{l}\text { Mention of the negative impacts of } \\
\text { capitalism on the environment }\end{array}$ & No \\
\hline
\end{tabular}


mentioned in at least $10 \%$ of the videos, a percentage that we deemed sufficient to allow for comparison. Others, such as the perception of technology, or a critique of the capitalist economic system of France and Mexico, were either not mentioned at all or featured in less than $10 \%$ of our sample.

The second step consisted of a structural analysis of the underlying stories contained in the videos; first, we explored our corpus to identify the elements that could work as features of stories, either as characters or as actions. We then selected those elements of the actantial model [Greimas, 1966] that were present in our corpus, as well as some of the events of a plot, according to Freytag's pyramid [Wheeler, 2004]: exposition, rising action, climax, falling action and resolution. Consequently, the videos were analyzed according to the diagram presented in Figure 1, in which triangles represent the actors of the underlying stories and squares represent actions. It is essential to emphasize that this diagram was established after the exploration of our corpus. In other words, this exploration led us to adapt the Greimas' model and Freytag's pyramid accordingly.

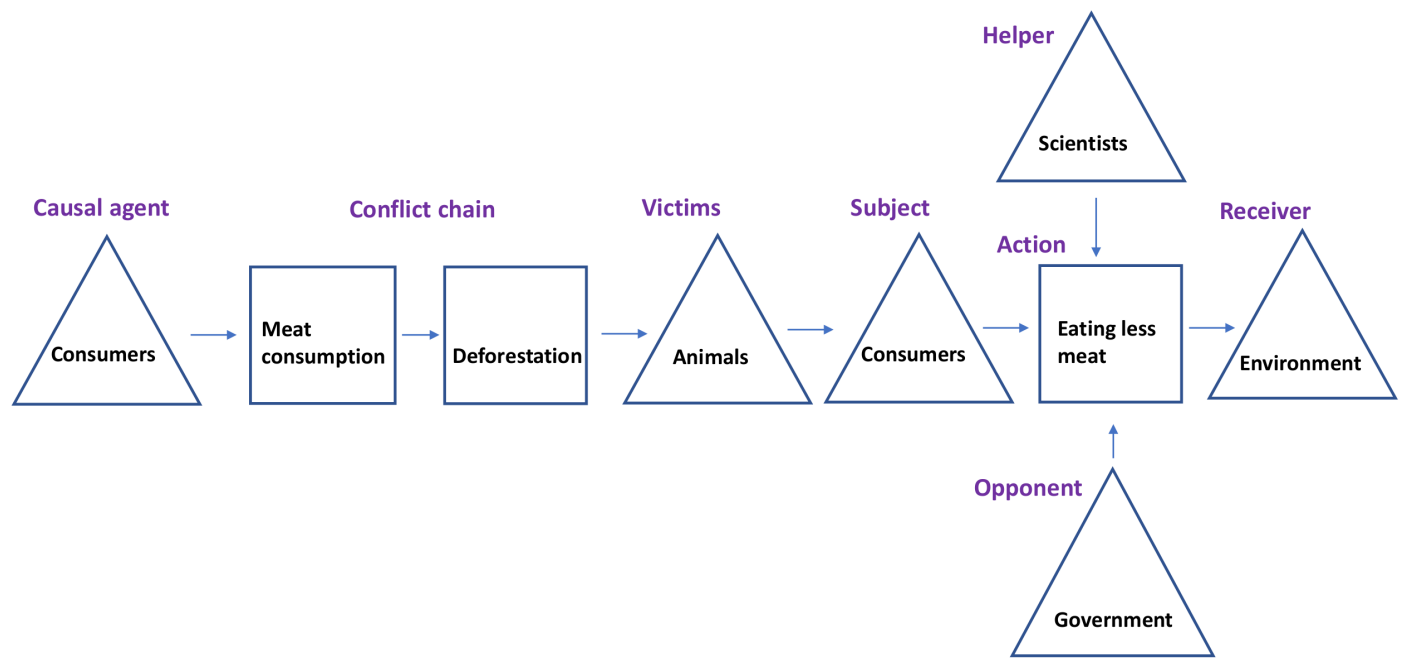

Figure 1. Example of narrative elements found in the environmental discourse of our sample of French and Mexican YouTube videos that address environmental problems by using an adaptation of the actantial model and Felystag's pyramid.

Besides identifying characters and actions, we tried to describe whether these were depicted in a positive or negative way.

1. Causal agent: the entity that produces an effect or is responsible for causing the environmental problem.

2. Chain of incidents: a sequence of events that leads to the environmental problem, i.e. human activities, and their impacts. In this case, because of the wide diversity of subjects addressed in our sample, we did not consider it adequate to classify the conflict incidents according to their contents. Instead, we determined whether these incidents corresponded to individual actions (e.g. overconsumption of water at home or throwing away too much garbage) or to collective actions (e.g. deforestation, agricultural impacts, overpopulation). 


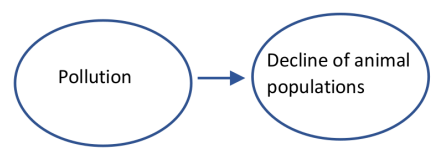

B. Intermediate - low : 3 to 4 elements

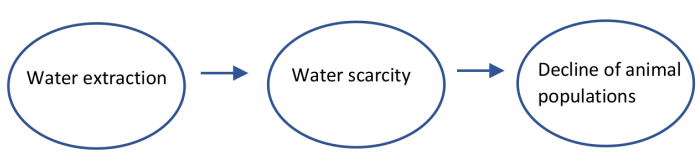

C. Intermediate-high : 5 to 6 elements

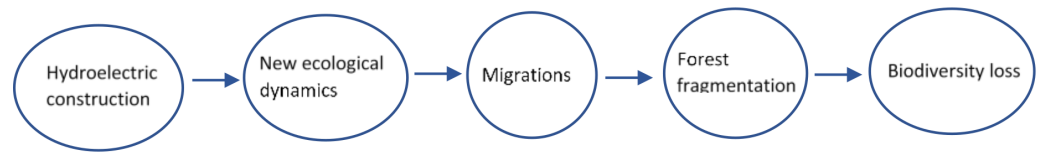

D. High : 7 or more elements

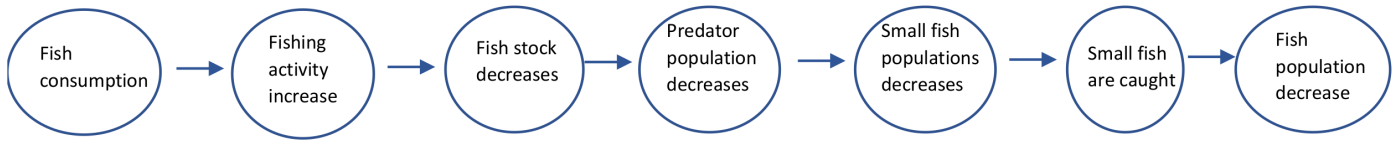

Figure 2. Classification of level of complexity of conflicts mentioned by French and Mexican YouTubers of our sample, according to the number of elements of each chain. (An example of each level of complexity is provided).

We also analyzed the "level of complexity" of the explanations to environmental problems given by them. We did this by counting the number of different causes of a given problem (chain of incidents), as shown in Figure 2. It is important to point out that that the environmental problems were not presented by the YouTubers in the depicted linear and simplified way but that we created this scheme based on our interpretation of their explanations.

We also identified the number of independent conflict chains, in other words, chains of factors not interrelated with each other, that lead to the same environmental problem or to a different one (Figure 3).

3. The subject is the protagonist of the story (a sort of hero). He/she tries to achieve environmental protection or to reduce environmental deterioration.

4. Actions are the specific activities that are suggested in order to tackle environmental problems. For the same reasons as in the conflict incidents, we did not analyse the content of the objects identified in our sample. Instead, we determined if they were direct or indirect environmental actions; in other words, if they corresponded to actions intended to have a direct impact on the environment or to voluntary and intentional actions targeted at influencing other people or structures in society in order to decrease the impact on the environment [Henriksson, 2011]. 


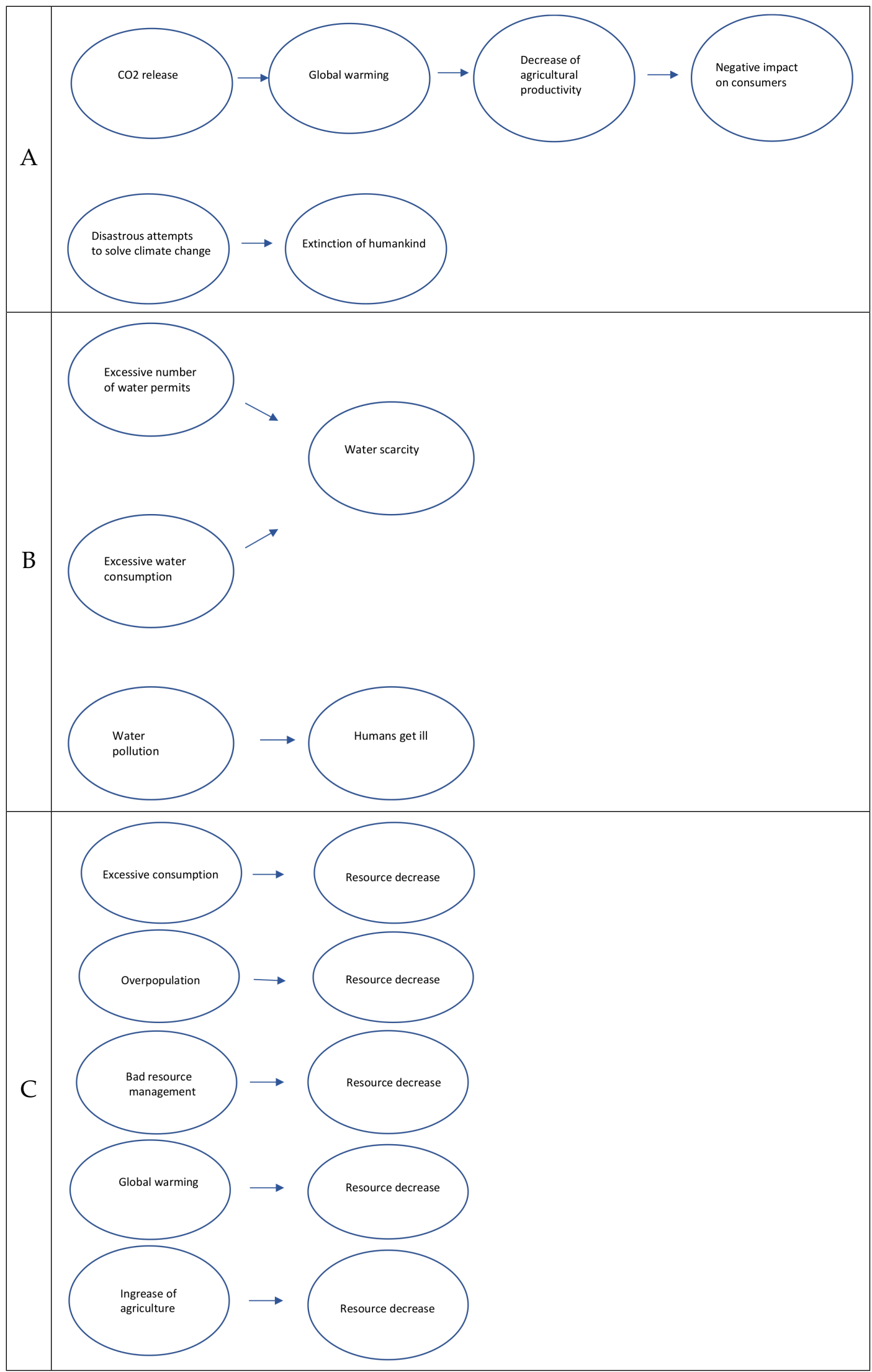

Figure 3. Level of complexity of conflict according to conflict chain number, in French and Mexican YouTube videos that address environmental problems. A: 1 to 2; B: 3 to 4; C: 5 or more. 
Additionally, we counted the proportion of videos which included individual actions (e.g., "use public transport", "eat less meat"); in other words., what we mentioned before as the individualisation and depoliticisation of environmental problems".

5. The helper supports the subject in carrying out the actions.

6. The opponent works against the helper and tries to prevent the subject from going through with the actions. It is worth pointing out the difference between "causal agent" and "opponent": the former originates the environmental problem, while the latter occurs later on, as an opposing force to the subject's "good actions".

7. The receiver benefits from the actions carried out by the subject.

Results works.
The video titles, the topic they address, the chain they belong to, as well as the day they were uploaded, and their number of views on the day they were found are included in the Annex. As it shows, the most frequent topics are pollution, biodiversity loss, and global warming, even when our search included general topics (searching for words such as "ecology", "ecological crises"), as well as other topics, such as dead zones and soil erosion. However, most videos address a main subject, and include others, such as deforestation, overpopulation, water scarcity, and health problems. It is also worth mentioning that approximately $80 \%$ of videos were uploaded from 2017 to 2019, and that the oldest one was from 2012. This could be explained by an increased interest in environmental matters in recent times, but it could also be related to the way YouTube's recommendation algorithm

Almost all the YouTubers in our sample are quite young (between 15 and 35 years old) and most of them do not have a degree in scientific or environmental topics. In the case of Mexican YouTubers, the vast majority live in the biggest cities of the country (Mexico City, Guadalajara, Monterrey and Puebla), while French YouTubers are more dispersed throughout the country (Paris, Lyon, Reims, Toulouse, Aveyron, Amiens, among others).

The videos belong to two types of YouTube channel: (1) channels that specialize in scientific and environmental matters, i.e., belonging to the so called "ed-tubers", and (2) channels that usually address other matters (fashion, travel, sensational stories or even paranormal events) and that from time to time upload a video addressing environmental matters. In this regard, there is a difference between the videos of the two nationalities from our sample: while three quarters of the French YouTubers of our sample regularly upload videos on subjects related to science, technology, politics or the environment, this is the case for less than a third of the Mexican YouTubers. The remainder normally upload humorous or sensationalist videos or address daily life matters. Instead, environmental issues are exceptions on these channels.

Additionally, the number of views differs greatly between videos, from 4000 to 12 million. This significant difference is due to the fact that the videos of our sample with less views are normally uploaded by YouTubers whose channels are devoted to scientific, social, or technological matters, while the videos with a 
higher number of views normally belong to popular YouTubers, who usually address fashion, or humorous, paranormal of sensationalist matters. The average number of views per video for Mexican videos was 2.2 million whereas for French videos this was 600 thousand. Nearly a quarter of the videos exceed one million views, $70 \%$ of which were Mexican. Furthermore, six Mexican and two French YouTubers from our sample are among the top ten in terms of number of subscribers to their channels [Carranza Alva, 2018; Rahmil, 2021].

There is also great diversity in terms of video duration. Around a quarter of them are less than five minutes in length, a third between 5 and 10 minutes; a quarter between 10 and 15 minutes and only just under $15 \%$ last more than 15 minutes.

\section{Location and scale of environmental problems}

We found that the majority of the videos in our sample either exclusively addressed global problems or addressed both global and local problems. For instance, $94 \%$ of videos mentioned the planet. Also, the number of videos that talked exclusively about the environmental problems of countries other than the YouTubers' country of origin was higher in French videos than in Mexican ones. Similarly, videos that only addressed the environmental problems of the YouTubers' country of origin was more frequent in the Mexican videos of our sample than in the French ones.

An interesting aspect is that nearly a third of French videos mentioned the differences between poor countries and rich ones or between people in those countries, in terms of economic or environmental conditions, or of the use of resources. For instance, when talking about water scarcity, a YouTuber from our sample stated: "Someone from Madagascar consumes 10 liters of water per day, while a French person needs 137 liters per day for their personal use". In contrast, in just one Mexican video was the difference between rich and poor countries mentioned. It is important to point out that there was not a single video where differences in consumption or environmental impact between rich and poor people within each country were pointed out. This observation is particularly interesting due to the fact that the field of research of "environmental justice" is increasingly emphasizing the fact that the socio-economic conditions of people are related to environmental problems in two ways: rich people contribute more to these problems than poor people [Dominelli, 2013], while the latter are more vulnerable to their consequences [Schlosberg and Collins, 2014].

\section{Ethical dimension}

Regarding the ethical dimension, in more than half of the videos, both French and Mexican, there were sentences expressing beliefs about what is morally right or wrong: "It is very disheartening to know just how much harm human beings are causing in such a short space time", or "You are right to change your mobile phone every year, in order for these kids to keep their job. You certainly don't want them to go to school, do you?", or "In 20-30 years there won't be any water left. What a pity". 


\section{The notions of nature and environment}

Another finding regards the way that the YouTubers of our sample refer to nature and the environment. In most cases, "nature" apparently refers to the wilderness or to lands with a low human presence, while "environment" seems to denote physical and biological elements that surround places with human presence (Table 3). While over $80 \%$ of videos mention the word "environment", only a third mention "nature". Both are frequently talked about as something separate from human beings (Table 4), for instance, by using phrases such as "help the environment" or "save the environment". Similarly, some YouTubers of our sample talk about the things that nature gives us as a separate entity from us. However, in a third of the videos, the link between human beings and the environment or nature is expressed through the mention of the impact that environmental problems have on human health, the scarcity of drinking water, etc. It is worth noting that none of the Mexican YouTubers of our sample refer to the indigenous cosmovision that is often praised in Latin-American political ecology [see for example Escobar, 2011] or in global "symmetrical anthropology" [see Descola, in Pazos, 2006]

Table 3. Examples of phrases used in the French and Mexican YouTube videos of our sample that address environmental problems, in which nature is viewed as wilderness.

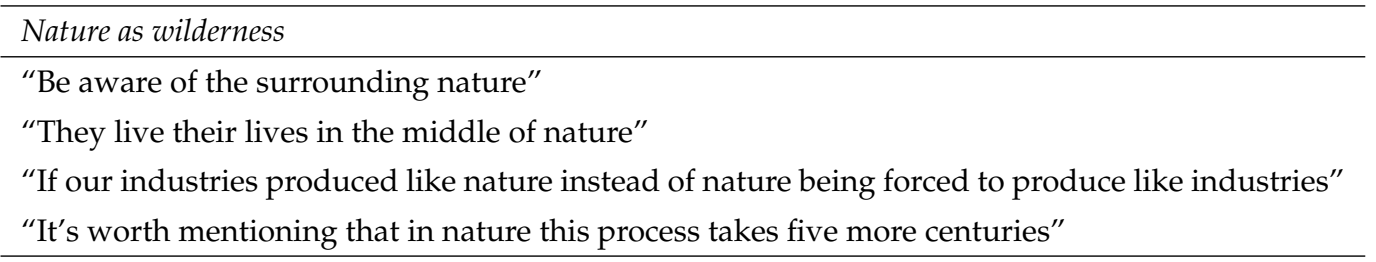

Table 4. Examples of phrases used in French and Mexican YouTube videos of our sample that address environmental problems, in which nature and the environment are viewed as separate from human beings.

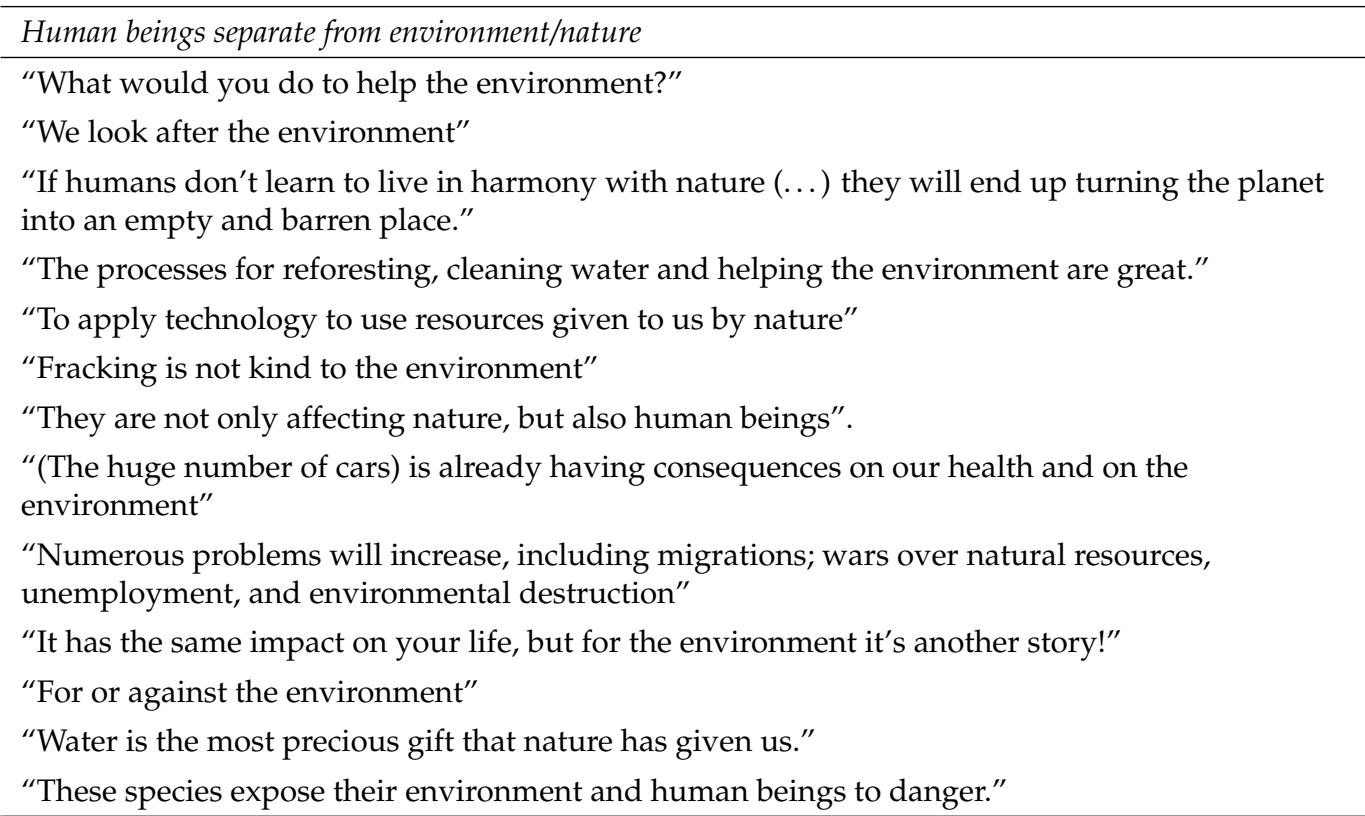


In some videos, the environment ("l'écologie" in the case of some French videos) is talked about as a subject. For instance, a French YouTuber sarcastically says that the environment is anxiety-provoking and others refer to it as a problem.

When speaking about damage or protection, the most used word is "environment". This word is also used in phrases that could be considered to be formulas, such as "environmental awareness", "environmental impact", "respectful of the environment", "environmental problems".

\section{Structural analysis of underlying stories}

We will proceed by presenting each of the elements of the diagram shown in Figure 1:

Causal agent. The "causal agent" was identifiable in $75 \%$ of our videos (half Mexican and half French). In two thirds of them the causal agent corresponded to humanity as a whole, expressed as "we", "man", "human beings" or "societies". In $25 \%$ of these videos, other causal agents were identified besides humanity, such as entrepreneurs and manufacturers $(23 \%)$. The government was also mentioned but in a smaller percentage of videos (12\%), mainly Mexican. It is worth pointing out that only three French videos mentioned our economic system as something that intensifies environmental problems.

Chain of incidents. Around $80 \%$ of videos included the chain of incidents. In most of them, both French and Mexican, the incidents corresponded exclusively to collective actions or phenomena, such as overfishing, water extraction, deforestation, overpopulation, the introduction of exotic species or fuel extraction. It is worth pointing out that most of them are carried out at an industrial scale.

A quarter of Mexican videos included individual actions (for instance, wearing fur, dumping garbage on the street, or eating meat), while this was the case for a quarter of French videos. The rest included both individual and collective actions. With regards to the "level of complexity", most videos (51\%) were classified as "simple" in terms of the number of different conflict chains. A third were classified as intermediate and $16 \%$ as complex. Nearly all of the latter were French (Table 5).

Table 5. Level of complexity in terms of number of conflict chains of French and Mexican YouTube videos that address environmental problems.

\begin{tabular}{lcc}
\hline Number of conflict chains & Mexican videos (\%) & French videos (\%) \\
\hline 1 to 2 & 61 & 43 \\
3 to 4 & 35 & 32 \\
5 or more & 4 & 25 \\
\hline
\end{tabular}

Instead, regarding the number of interrelated incidents of each chain, the majority of Mexican videos of our sample had few interrelated incidents, while nearly $70 \%$ of French videos had chains consisting of 5 or more incidents (Table 6). Therefore, the French videos from our sample have a higher level of complexity, according to our two criteria. 
Table 6. Level of complexity in terms of number of incidents of each conflict chain, in the French and Mexican YouTube videos of our sample that address environmental problems.

\begin{tabular}{lcc}
\hline $\begin{array}{l}\text { Number of incidents } \\
\text { in conflict chains }\end{array}$ & Mexican videos (\%) & French videos (\%) \\
\hline 1 to 2 & 35 & 21 \\
3 to 4 & 30 & 11 \\
5 to 6 & 30 & 43 \\
7 or more & 4 & 25 \\
\hline
\end{tabular}

Victims. As mentioned before, our analysis regarding the conflict consisted of identifying the type of organisms or entities affected by it. Firstly, it is worth noting that humans were pointed out as those affected in more than two thirds of French videos, and in half of the Mexican videos of our sample. This resulted from air or water pollution, a lack of drinking water, an increase in temperature and of the sea level, decrease of agriculture, etc. Similarly, French videos mentioned other living beings more frequently than Mexican ones. These ones were said to be mainly affected by water pollution, habitat loss or degradation and overexploitation. In the case of the Mexican videos, the planet was mentioned as the "victim" of the chain of incidents in four videos. We can note that integrated systems, such as ecosystems and landscapes, were scarcely mentioned (in just five French videos and in two Mexican ones).

Subject. As stated earlier, the subject is the protagonist of the story, the one trying to solve environmental problems. This role was identifiable in $70 \%$ of our sample (half French and half Mexican). The agent that was most frequently mentioned as such, both in the French and Mexican videos, was humanity as a whole. For this purpose, YouTubers would refer to humanity in the first-person plural (e.g. "If our industries produced like nature instead of nature being forced to produce like industries", "We can approach environmental organizations") or they may suggest specific actions to the audience by using the second-person ("We suggest that you use public transport").

In three Mexican videos of our sample the government played the role of the subject. Other entities pointed out by both Mexican and French videos as subjects, with less frequency than humanity, were ecological organizations and scientists.

Actions. The YouTuber suggested actions to solve the environmental problem in question in three quarters of our sample (half French and half Mexican). Most videos included individual actions, either in addition to collective actions (e.g. "invest in clean technologies", "improve social development") or exclusively individual actions. Additionally, the majority of suggested individual actions corresponded to direct environmental actions such as reducing meat consumption, drinking tap water and avoiding the use of straws, while the rest were indirect environmental actions, such as informing oneself or friends. It is also worth mentioning that French videos included a higher proportion of the former kind of action (80\%) than Mexican videos (56\%). 
Helpers. This role was only found in less than $30 \%$ of the Mexican videos of our sample and $40 \%$ of the French ones. In both cases, the vast majority of helpers were scientists. Other entities that were mentioned as helpers with much less frequency were ecological organizations in both types of videos; the government and the media in Mexican videos, and banks in French ones.

The kind of "help" offered by scientists was mainly described as carrying out research and giving information, and with less frequency, denouncing environmental issues and creating environmental awareness. With regard to the government and banks, they were mentioned as monetary investors, while the government was also pointed out for its role in forbidding activities that harm the environment or as an institution that proposes ideas. The ecological corporations were described as offering ecological-friendly products, and ecological organizations as carrying out environmental protection actions, such as reforestation.

Opponents. The opposing force to the subject's actions was identified in only one quarter of our sample. The government played the role of the opponent in nearly $90 \%$ of Mexican videos and in $60 \%$ of the French ones, while in half of the latter, corporations played this role. In a limited number of Mexican videos, the role of the opponent was played by corporations, scientists, and doctors. In French videos this was the case for scientists and the media. We can correlate this observation with the afore-mentioned results about the identified "causal agent": as the causal agent is mainly "humanity as a whole", it is not surprising that the opponent is fairly unclear, or at least may be impersonated by a wide range of actors. However, we can stress that while diverse, these actors all belong to a kind of "social elite".

While Mexican YouTubers described their government as corrupt and dishonest, in most French videos in which the government played the role of the opponent, it was portrayed as useless. In the case of corporations, they were always portrayed as abusive and amassing wealth at the expense of the environment. Some scientists were portrayed by one French YouTuber, as well as by a Mexican one, as fraudulent. The media were presented in a similar way by a French YouTuber, and doctors as abusive by a Mexican one.

It is worth noting that the government features more frequently in Mexican videos than in French ones, playing either the role of the causal agent, the opponent or even the subject.

Receivers. This role was identified in only $15 \%$ of Mexican videos and in less than $10 \%$ of the French videos of our sample. In the former, most receivers were the planet, while this was the case for two French videos. Other victims were the environment, both in the French and Mexican videos while in the former, future generations were also mentioned.

\section{So, what is the main environmental story told by French and Mexican YouTubers?}

Humanity as a whole is to blame for harming the environment and, in doing so, it harms itself, as well as other living beings. However, even if humanity as a whole 
is shown as being responsible for harming the environment, the specific destructive activities mainly correspond to industrial ones.

Humans overall are also responsible for reducing the harmful effects of their actions, which would benefit the planet and its environment. The main actions to be undertaken are individual direct environmental actions. Scientists will be supportive by carrying out research and providing information. Other supportive actors are ecological organizations and corporations. From one perspective, the government will act as a force that opposes environmental wellbeing because it is corrupt and incompetent. In the French version of the story, corporations also play this role due to their economic interests and abusive nature.

We found a similar environmental discourse in the French and Mexican videos of our sample, in terms of the actors and roles in their narratives, as well as the ethical dimension of these narratives, and the self-blaming speech. This finding could contribute to corroborating the idea that globalization exists in environmental discourse. Given that Mexico has an important presence of indigenous populations, with their own environmental knowledge and environmental perceptions, it is unsurprising that these factors are somehow expressed in our sample. However, indigenous people in Mexico mostly live in rural locations, in conditions of poverty [Villagómez Ornelas, 2019] and their knowledge has been marginalized for centuries [Kleiche-Dray and Waast, 2016]. In contrast, there is a very strong influence from the United States through its films, music, fashion, etc., all of which have a visible impact on the Mexican way of dressing, talking, also affecting their beliefs [Acle Mena, Santos Díaz and Silva Carmona, 2018]. As the Mexican YouTubers from our sample are all urban dwellers, it is probable that they are particularly susceptible to this influence. On the other hand, as several of them are "digital celebrities", it is likely that they themselves contribute to the globalization of environmental discourse.

Another possible explanation for the globalization of environmental discourse is the fact that YouTube is in itself a global platform. However, this should be analyzed in depth, as local- or culturally-based videos (e.g. rumors concerning local stars, comments about local political affairs, etc.) are also present in this platform.

One aspect that stands out in this globalized narrative is the apparent incoherence between the damaging activities and the suggested actions, as the former are mostly actions carried out by society in a collective way, while the latter are mainly individual daily actions. One possible explanation is that the "liberal" narrative we presented in part one is widely admitted in our corpus: as Wiedmann et al. [2020] state, consumers' decisions are thought to set in motion larger scale activities that produce environmental impacts. More broadly, our corpus seems to embrace a form of individualist sociology where society is nothing more than the sum of the free action of each individual. This underlying belief, while never explicit in the videos, may explain the apparent gap between the attribution of responsibility to "society", "governments" and "companies" and the search for a solution in consumers' or individuals' behaviors, the former being considered the mere expression of the latter. Similarly, it is worth noting that the questioning of the economic and social systems, which are considered highly responsible for current environmental problems by a large part of contemporary environmentalist 
discourse [see for example Jackson, 2009] is rare in our sample. This observation and the previous one seem in line with what Comby [2017] calls the depoliticization of environmental problems: they are not seen (or presented) as a collective, and thus political, phenomenon on which people could act by political means such as protests, voting, associations, collective empowerment, civil disobedience and so on. One of the conclusions we could draw from this is that public communication on environmental subjects could highlight their political dimension in order to raise public awareness about them.

In a rather similar perspective, we can see that blaming humanity for environmental deterioration was a strong part of environmental discourse in our corpus and that scholars in disciplines such as political ecology have pointed out that the current environmental crisis has been caused by political and economic systems, attributable to certain people from specific countries [Canabate, 2019]. According to a recent study carried out by Oxfam and the Stockholm Environment Institute, from 1990 to 2015, the wealthiest $1 \%$ of the world population were responsible for more than double of the production of carbon dioxide than a half of the poorest world inhabitants [Harvey, 2020]. Similarly, one interesting finding is that differences in consumption habits and environmental impacts between rich and poor people from each country were not mentioned at all in our sample. In particular, in the case of Mexico this difference is starkly clear given its high income distribution inequality. For instance, according to Santillán Vera and de la Vega Navarro [2019], in 2014, the poorest household decile emitted on average 1.6 tons of carbon dioxide per capita, while the wealthiest decile reached 8.6 tons per capita of this gas. When talking about accountability, a desirable situation might be that society had a clear idea of who is responsible for which kind of environmental damage in order to urge each actor to act responsibly or to be able to more precisely consider the best political measures to be taken.

In other respects, the focus on individual behavior, and more particularly on individual consumption, in our corpus can be discussed in light of the literature on environmental communication. Indeed, individuals are blamed for environmental problems with the intention of enhancing actions to tackle these problems. This has several implications. Firstly, there is the ethical dimension of producing this negative emotion in the audience, discussed at length by Guttman and Salmon [2004]. Secondly, there is a growing body of literature on the counter-productive effects of guilt on pro-environmental behavior that range from denial to depression linked to the feeling of powerlessness [Chédotal et al., 2017]. Thirdly, when talking specifically about consumption, guilt could contribute to what Fontenelle [2013] it calls for the production of "an eschatological view of the end of the human species because of the hyper-consumerism of modern societies". This author points out that, in this "new environmental paradigm", guilt is re-signified within the context of the media and marketing, so that it is possible to continue consuming but instead buying products from environmentally responsible corporations. This assertion echoes our study in the following way: most of the YouTubers from our sample, especially those considered to be influencers, normally upload videos that talk about fashion, make-up, plane trips, videogames, etc., all of which form part of a consumerist way of life. In their "pro-environment" video, their suggested solutions frequently have to do with using eco-friendly products. This double observation is consistent with Fontenelle's claim [2013]: the fact that the YouTuber questions some kinds of consumerism and not consumerism in itself by suggesting 
good and bad behaviors within consumerism may contribute to reinforcing it, either by normalizing it or by presenting it as an obvious solution to environmental issues.

In a completely different perspective, we noted a clear difference in our corpus between the French and Mexican videos, namely, the tendency of the latter to address the environmental problems of their own country, while the French videos frequently talk about issues occurring in countries other than France. Several French YouTubers also mention the differences between rich and poor countries. This might be explained by the fact that the severity of environmental problems is more serious in poor countries than in France. It could also be possible that these findings relate to France's past, perhaps even to what Goradia [2018] calls Europeans' self-guilt, due to their experience of colonizing other countries with the well-known negative results for those countries. Perhaps this event makes them more attentive to problems occurring in other parts of the world.

The limitations of this study include the relatively small sample size, and the use of French and Mexican videos exclusively. Despite these limitations, this study is one of the first to examine the environmental narratives on YouTube. It would be interesting to extend this analysis to other digital media, such as to Facebook, Instagram, TikTok, etc., which have different audiences as well as other production features. It could also be interesting to analyze videos from countries that are more culturally diverse from France and Mexico, as the latter has been highly influenced by Western culture. Finally, it is worth pointing out that because of the vast number of videos uploaded to YouTube (around 500 hours per minute) [Gautier, 2019], the same analysis could be performed in a year or two, and it may be interesting to compare both results.

This study of narratives in environmental discourse could help to understand how people make sense of environmental problems and it could also contribute to improving communication efforts in order to allocate causes, effects and suggested actions in such a way that could be beneficial for environmental protection.

\section{Conclusion}

This study of narratives in environmental discourse could help to understand how people make sense of environmental problems and it could also contribute to improving communication efforts in order to allocate causes, effects and suggested actions in such a way that could be beneficial for environmental protection. For instance, in terms of environmental justice, it could be helpful to inform society on the actors who are responsible for significant damage to the environment. This could also help in terms of tackling this damage. Similarly, raising awareness about the environmental costs of our current economic systems could contribute to promoting a healthier environment and, consequently, to improving human wellbeing.

The fact that YouTube is an ever-growing discursive arena, notably popular among young people, and that there are just a few studies on environmental discourse on this platform makes this research even more relevant.

Our results point to the globalization of environmental discourse, a contradiction between the collective causes of environmental problems and the proposed 
individual solutions, and also the individualization and, therefore, depoliticization of environmental issues

Further research could study narratives of environmental discourses in other digital media, as well as the YouTube videos of other nationalities, in order to determine if they are consistent with our findings.

Appendix A.
General
characteristics of
videos included in
the analysis of
French and
Mexican YouTube
videos that
address
environmental
problems

\begin{tabular}{|c|c|c|c|c|c|c|}
\hline Nationality & Title & YouTuber's name & Main subject & Upload date & $\begin{array}{l}\text { Number } \\
\text { of views } \\
\text { (7/08/2019) }\end{array}$ & $\begin{array}{l}\text { Duration } \\
\text { (minutes) }\end{array}$ \\
\hline \multirow[t]{26}{*}{ French } & Ecology & Kemar & Several subjects & $18 / 04 / 2015$ & 2 million & 6 \\
\hline & $\begin{array}{l}\text { An ecological gym!! } \\
(2,000,000 €)\end{array}$ & Tibo in Shape & Energy & $8 / 02 / 2017$ & 1.9 million & 8 \\
\hline & $\begin{array}{l}\text { The world will end } \\
\text { soon? }\end{array}$ & JOYCA & Overpopulation & $31 / 03 / 2019$ & 1.5 million & 15 \\
\hline & $\begin{array}{l}7 \text { animals that destroy } \\
\text { the Earth }\end{array}$ & Trash & Biodiversity loss & $11 / 06 / 2017$ & 1.4 million & 8 \\
\hline & $\begin{array}{l}\text { Don't eat tomatoes, } \\
\text { especially in winter! }\end{array}$ & Le Tatou & Pollution & $23 / 01 / 2018$ & 1 million & 13 \\
\hline & $\begin{array}{l}\text { Must we believe in } \\
\text { global warming? }\end{array}$ & Science étonnante & Global warming & $27 / 11 / 2015$ & 892 thousand & 17 \\
\hline & Water & $\begin{array}{l}\text { Et toute le monde } \\
s^{\prime} \text { en fout }\end{array}$ & Water scarcity & $31 / 03 / 2017$ & 840 thousand & 4 \\
\hline & $\begin{array}{l}\text { To solve } \\
\text { overpopulation }\end{array}$ & Dirty Biology & Overpopulation & $14 / 03 / 2017$ & 770 thousand & 13 \\
\hline & $\begin{array}{l}\text { To tear up paper } \\
\text { means destroying the } \\
\text { Amazon region }\end{array}$ & MaxBird & Biodiversity loss & $11 / 01 / 2019$ & 600 thousand & 7 \\
\hline & $\begin{array}{l}10 \text { animals that } \\
\text { disappeared because } \\
\text { of man }\end{array}$ & Lama Faché & Biodiversity loss & $22 / 04 / 2018$ & 562 thousand & 11 \\
\hline & $\begin{array}{l}\text { Top } 5 \text { most polluted } \\
\text { places }\end{array}$ & Dr Nozman & Pollution & $2 / 08 / 2015$ & 562 thousand & 5 \\
\hline & $\begin{array}{l}3 \text { surprising things of } \\
\text { our pollution }\end{array}$ & Poisson Fécond & Pollution & $1 / 12 / 2017$ & 561 thousand & 13 \\
\hline & $\begin{array}{l}\text { What if all the trees } \\
\text { disappeared? }\end{array}$ & Poisson Fécond & Biodiversity loss & $19 / 02 / 2018$ & 560 thousand & 9 \\
\hline & $\begin{array}{l}\text { The Gold Mountain is } \\
\text { a fortune for Guyane }\end{array}$ & MaxBird & Pollution & $20 / 09 / 2018$ & 555 thousand & 5 \\
\hline & $\begin{array}{l}\text { In the middle of corals } \\
\text { in Tahiti! }\end{array}$ & Dr Nozman & Biodiversity loss & $8 / 11 / 2017$ & 525 thousand & 11 \\
\hline & $\begin{array}{l}\text { How to move the } \\
\text { planet }\end{array}$ & DirtyBiology & Global warming & $9 / 06 / 2016$ & 510 thousand & 6 \\
\hline & Shale gas & $\begin{array}{l}\text { Professeur } \\
\text { Feuillage }\end{array}$ & Pollution & $21 / 09 / 2014$ & 263 thousand & 14 \\
\hline & Waste & $\begin{array}{l}\text { Et toute le monde } \\
s^{\prime} \text { en fout }\end{array}$ & Pollution & $7 / 01 / 2017$ & 500 thousand & 4 \\
\hline & $\begin{array}{l}10 \text { ways or reducing } \\
\text { your waste }\end{array}$ & $\begin{array}{l}\text { Les astuces de } \\
\text { Margaux }\end{array}$ & Pollution & $10 / 03 / 2018$ & 258 thousand & 12 \\
\hline & $\begin{array}{l}10 \text { tips for reducing } \\
\text { your waste! }\end{array}$ & EnjoyPhoenix & Pollution & $1 / 09 / 2018$ & 256 thousand & 16 \\
\hline & Water & Nicolas Meyreux & Water scarcity & $28 / 09 / 2018$ & 200 thousand & 7 \\
\hline & Overfishing & Nicolas Meyreux & Biodiversity loss & $13 / 03 / 2019$ & 175 thousand & 7 \\
\hline & $\begin{array}{l}\text { Deforestation is a } \\
\text { positive thing! }\end{array}$ & Ami des lobbies & Biodiversity loss & $28 / 01 / 2019$ & 172 thousand & 5 \\
\hline & Deforestation & Neezay & Biodiversity los & $27 / 09 / 2018$ & 170 thousand & \\
\hline & Biodiversity in danger & $\begin{array}{l}\text { Professeur } \\
\text { Feuillage }\end{array}$ & Biodiversity loss & $15 / 05 / 2015$ & 93 thousand & 12 \\
\hline & $\begin{array}{l}\text { Deforestation: Don't } \\
\text { be such a fool }\end{array}$ & Mouton Lucide & Biodiversity loss & $24 / 08 / 2016$ & 40 thousand & 7 \\
\hline
\end{tabular}




\begin{tabular}{|c|c|c|c|c|c|c|}
\hline \multirow[t]{7}{*}{ Nationality } & Title & YouTuber's name & Main subject & Upload date & $\begin{array}{c}\text { Number } \\
\text { of views } \\
(7 / 08 / 2019)\end{array}$ & $\begin{array}{l}\text { Duration } \\
\text { (minutes) }\end{array}$ \\
\hline & $\begin{array}{l}5 \text { things to change } \\
\text { your city }\end{array}$ & $\begin{array}{l}\text { Partager c'est } \\
\text { sympa }\end{array}$ & Global warming & $27 / 05 / 2018$ & 37 thousand & 5 \\
\hline & $\begin{array}{l}\text { Do we save the planet } \\
\text { from plastic? }\end{array}$ & Lea Camilieri & Pollution & $21 / 02 / 2019$ & 35 thousand & 5 \\
\hline & $\begin{array}{l}1000 \text { billion to save the } \\
\text { weather }\end{array}$ & Florence Porcel & Global warming & $16 / 07 / 2018$ & 28 thousand & 16 \\
\hline & Dead zones & Mouton Lucide & Dead zones & $21 / 04 / 2017$ & 26 thousand & 3 \\
\hline & $\begin{array}{l}\text { Do we currently cut } \\
\text { more trees in the } \\
\text { Amazon than before? }\end{array}$ & Mister Geopolitix & Deforestation & $1 / 05 / 2017$ & 14 thousand & 3 \\
\hline & Fish and overfishing & Le réveilleur & Biodiversity loss & $11 / 04 / 2017$ & 14 thousand & 18 \\
\hline \multirow[t]{23}{*}{ Mexican } & $\begin{array}{l}7 \text { animals that men } \\
\text { killed until they } \\
\text { disappeared }\end{array}$ & Badabun & Biodiversity loss & $24 / 03 / 2018$ & 13 million & 7 \\
\hline & $\begin{array}{l}\text { The most polluted } \\
\text { beach in the world }\end{array}$ & LuisitoComunica & Pollution & $31 / 01 / 2018$ & 6.4 million & 12 \\
\hline & The Earth is dying & Dankev & Global warming & $25 / 11 / 2017$ & 5 million & 9 \\
\hline & $\begin{array}{l}\text { This strange little } \\
\text { animal in danger of } \\
\text { becoming extinct }\end{array}$ & LuisitoComunica & Biodiversity loss & $7 / 09 / 2018$ & 4.9 million & 13 \\
\hline & $\begin{array}{l}\text { What do we do with } \\
2.6 \text { million dollars? }\end{array}$ & Juan Pa Zurita & Water scarcity & $30 / 05 / 2017$ & 4.1 million & 18 \\
\hline & The hour of the planet & WereverTomorrow & Energy & $30 / 03 / 2012$ & 3.7 million & 12 \\
\hline & $\begin{array}{l}\text { Questions that I } \\
\text { avoided }\end{array}$ & Caelike & Pollution & $22 / 05 / 2018$ & 3.5 million & 4 \\
\hline & $\begin{array}{l}\text { The government has } \\
\text { given us shit and no } \\
\text { one says a thing }\end{array}$ & Badabun & Pollution & $18 / 11 / 2018$ & 2.7 million & 10 \\
\hline & $\begin{array}{l}\text { What would you do to } \\
\text { save the planet? }\end{array}$ & Nonoscortes & Pollution & $25 / 03 / 2018$ & 2.6 million & 5 \\
\hline & Pollution & Luisito Rey & Pollution & $5 / 05 / 2016$ & 1.9 million & 7 \\
\hline & $\begin{array}{l}\text { The video that the } \\
\text { damns government } \\
\text { does not want you to } \\
\text { see }\end{array}$ & Badabun & Pollution & $4 / 08 / 2018$ & 1.2 million & 6 \\
\hline & $\begin{array}{l}8 \text { animals that will } \\
\text { disappear in } 2019\end{array}$ & TeVere & Biodiversity loss & $30 / 01 / 2019$ & 800 thousand & 10 \\
\hline & $\begin{array}{l}\text { Don't ever throw } \\
\text { garbage into the } \\
\text { oceans }\end{array}$ & $\begin{array}{l}\text { Planeta de los } \\
\text { Secretos }\end{array}$ & Pollution & $6 / 09 / 2018$ & 781 thousand & 4 \\
\hline & Is climate change real? & Curiosamente & Global warming & $15 / 05 / 2016$ & 700 thousand & 7 \\
\hline & Water & $\begin{array}{l}\text { El Pulso de la } \\
\text { República }\end{array}$ & Water scarcity & $29 / 07 / 2018$ & 600 thousand & 18 \\
\hline & $\begin{array}{l}\text { Climate change: real } \\
\text { or fake? }\end{array}$ & Werefenews & Global warming & $19 / 05 / 2019$ & 315 thousand & 15 \\
\hline & $\begin{array}{l}\text { What you need to do } \\
\text { to be ecologically } \\
\text { friendly }\end{array}$ & Yosstop & Several subjects & $14 / 02 / 2019$ & 300 thousand & 4 \\
\hline & Today for the planet & Yosstop & Pollution & $10 / 06 / 2019$ & 129 thousand & 16 \\
\hline & $\begin{array}{l}\text { You are also an } \\
\text { asshole }\end{array}$ & Diego Dreyfus & Global warming & $21 / 04 / 2019$ & 121 thousand & 4 \\
\hline & $\begin{array}{l}\text { Was the cancellation } \\
\text { of the new airport a } \\
\text { bad thing? }\end{array}$ & Arnoldo Montaño & Water scarcity & $15 / 11 / 2018$ & 75 thousand & 16 \\
\hline & $\begin{array}{l}\text { The best video about } \\
\text { global warming }\end{array}$ & Film Maker TV & Global warming & $9 / 03 / 2018$ & 75 thousand & 6 \\
\hline & $\begin{array}{l}6 \text { Mexican animals in } \\
\text { danger of extinction }\end{array}$ & Morboxis & Biodiversity loss & $06 / 06 / 2016$ & 52 thousand & 3 \\
\hline & $\begin{array}{l}\text { Are humans a plague } \\
\text { for the planet? }\end{array}$ & Arnoldo Montaño & Several subjects & $20 / 02 / 2019$ & 44 thousand & 12 \\
\hline
\end{tabular}




\begin{tabular}{|c|c|c|c|c|c|c|}
\hline Nationality & Title & YouTuber's name & Main subject & Upload date & $\begin{array}{c}\text { Number } \\
\text { of views } \\
\text { (7/08/2019) }\end{array}$ & $\begin{array}{l}\text { Duration } \\
\text { (minutes) }\end{array}$ \\
\hline & Mexican biodiversity & Profe Dhito & Biodiversity loss & $30 / 08 / 2016$ & 20 thousand & 4 \\
\hline & The sixth extinction & $\begin{array}{l}\text { Colectivo } \\
\text { Hojarasca }\end{array}$ & Biodiversity loss & $22 / 04 / 2018$ & 18 thousand & 4 \\
\hline & $\begin{array}{l}\text { Air and water } \\
\text { pollution }\end{array}$ & Profe Dhito & Pollution & $11 / 10 / 2016$ & 14 thousand & 4 \\
\hline & $\begin{array}{l}\text { Where does water } \\
\text { supplied to your } \\
\text { house come from? }\end{array}$ & Planeteando & Pollution & $28 / 11 / 2018$ & 12 thousand & 4 \\
\hline & $\begin{array}{l}\text { The world will end by } \\
2030\end{array}$ & $\begin{array}{l}\text { Mundo de } \\
\text { MizTerio }\end{array}$ & Water scarcity & $21 / 06 / 2018$ & 8 thousand & 7 \\
\hline & $\begin{array}{l}\text { Microorganisms that } \\
\text { eat plastic? }\end{array}$ & $\begin{array}{l}\text { La Ciencia detrás } \\
\text { de }\end{array}$ & Pollution & $13 / 04 / 2018$ & 4 thousand & 7 \\
\hline & $\begin{array}{l}\text { If global warming } \\
\text { exists, why is it so } \\
\text { cold these days? }\end{array}$ & Planeteando & Global warming & $26 / 07 / 2018$ & 2 thousand & 2 \\
\hline & $\begin{array}{l}\text { The consequences of } \\
\text { fracking on } \\
\text { biodiversity }\end{array}$ & Cielos Despejados & Pollution & $06 / 09 / 2018$ & 2 thousand & 9 \\
\hline
\end{tabular}

References
Aarva, P. and Pakarinen Tampere, M. (2006). 'Studying the striving and opposing forces in newspaper journalism: the actantial model of health promotion'. Health Promotion International 21 (2), pp. 160-168.

https://doi.org/10.1093/heapro/dal010.

Acle Mena, R. S., Santos Díaz, J. Y. and Silva Carmona, J. L. (2018). 'Estados Unidos y su influencia cultural en los adolescentes mexicanos'. In: Dinámicas urbanas y perspectivas regionales de los estudios culturales y de género. Mexico City, Mexico: Universidad Nacional Autónoma de México y Asociación Mexicana de Ciencias para el Desarrollo Regional.

URL: http://ru.iiec.unam.mx/id/eprint/4416.

Ake-Kob, A. (2020). 'Goffman and the Mafia: shaping YouTube's technological affordances in the war on drugs'. Tapuya: Latin American Science, Technology and Society 3 (1), pp. 493-511. https://doi .org/10.1080/25729861.2020.1764302.

Allgaier, J. (2019). 'Science and environmental communication on YouTube: strategically distorted communications in online videos on climate change and climate engineering'. Frontiers in Communication 4, 36.

https://doi.org/10.3389/f comm.2019.00036.

Alonzo González, R. M. (2020). 'Intellectual property rights and social media policies for user-generated content: some lessons from Mexico'. In: The politics of technology in Latin America: data protection, homeland security and the labor market. Ed. by A. Plaw, B. Carvalho Gurgel and D. Ramírez Plascencia. Vol. 1. London, U.K.: Routledge. https://doi.org/10.4324/9780429342745-11.

Aranda-Ramírez, P. M., Moreno-Meza, G. P. and Tunal-Santiago, G. (2017). ‘La reconfiguración espacial de los jóvenes a través de YouTube. Caso: Ciudad de México'. Investigación y Postgrado 32 (2), pp. 37-56. URL: https: //revistas . upe l.edu.ve/index.php/revinpost/article/view/6590.

Audier, S. (2019). L'âge productiviste: hégémonie prométhéenne, brèches et alternatives écologiques. Paris, France: La Découverte.

Berger, P. L. and Luckmann, T. (1966). The social construction of reality: a treatise in the sociology of knowledge. Harlow, U.K.: Penguin Books. 
Bonneuil, C. (2019). La crise écologique, quelle histoire? Par Christophe Bonneuil. Conférence donnée pour le Cycle Pluridisciplinaire d'Études Supérieures (CPES), Université PSL. Paris, France, 6th February 2019.

URL: https : / /www . youtube . com/watch?v=C5fMGkLOSmg\%5C\&t=2862s.

Bourg, D. and Papaux, A. (2015). 'La pensée écologique'. In: Dictionnaire de la pensée écologique. Ed. by D. Bourg and A. Papaux. Paris, France: Puf.

Bruner, J. (1991). 'The narrative construction of reality'. Critical Inquiry 18 (1), pp. 1-21. https://doi.org/10.1086/448619.

Canabate, A. (2019). Comment refonder notre vision du progrès: la critique écologique au prisme de la réalité. Maison des Sciences Economiques, Paris, France, 11th June 2019. URL: https: //www . youtube. com/watch?v=gxbxUQm84ZY\%5C\&t=564s.

Cárdenas, A., Ballesteros, C. and Jara, R. (2017). 'Redes sociales y campañas electorales en Iberoamérica. Un análisis comparativo de los casos de España, México y Chile'. Cuadernos.Info 41, pp. 19-40. https://doi.org/10.7764/cdi.41.1259.

Carranza Alva, P. (17th May 2018). 'Los 12 'influencers' mexicanos más populares'. Publimetro. URL: https://www. publimetro.com.mx/mx/entretenimiento/2018 /05/17/los-12-influencers-mexicanos-mas-populares.html.

Chédotal, C., Berthe, B., de Peyrelongue, B. and Le Gall-Ely, M. (2017). 'L'utilisation de la culpabilité en communication'. Recherche et Applications en Marketing (French Edition) 32 (4), pp. 97-116. https://doi.org/10.1177/0767370116688650.

Comby, J.-B. (25th April 2017). 'La lutte écologique est avant tout une lutte sociale'. Ballast. URL: https://www.revue-ballast.fr/jean-baptiste-comby/.

Da Silva, J. (2019). 'L'empowerment féminin noir sur YouTube en France'. Terminal. Technologie de l'information, culture E société 125-126. https://doi.org/10.4000/terminal.5453.

Dominelli, L. (2013). 'Environmental justice at the heart of social work practice: greening the profession'. International Journal of Social Welfare 22 (4), pp. 431-439. https://doi.org/10.1111/ijsw.12024.

Escobar, A. (2011). 'Ecología política de la globalidad y la diferencia'. In: La naturaleza colonizada: ecología política y minería en América Latina. Ed. by H. Alimonda. Buenos Aires, Argentina: Ediciones CICCUS-CLACSO.

Fontenelle, I. (2013). 'From politicisation to redemption through consumption: the environmental crisis and the generation of guilt in the responsible consumer as constructed by the business media'. Ephemera: Theory and Politics in Organization 13 (2), pp. 339-366.

Gautier, M. (12th September 2019). 'YouTube: faits et chiffres'. Statista. URL: https://fr.statista.com/themes/3832/youtube/\#dossierKeyfigures.

Goradia, P. (22nd December 2018). 'Europe is trapped in self-guilt'. Sunday Guardian Live. URL: https://www. sundayguardianlive.com/opinion/europe-t rapped-self-guilt.

Greimas, A. J. (1966). 'Éléments pour une théorie de l'interprétation du récit mythique'. Communications 8: Recherches sémiologiques: l'analyse structurale du récit, pp. 28-59. https://doi .org/10.3406/comm.1966.1114.

Guttman, N. and Salmon, C. T. (2004). 'Guilt, fear, stigma and knowledge gaps: ethical issues in public health communication interventions'. Bioethics 18 (6), pp. 531-552. https://doi.org/10.1111/j.1467-8519.2004.00415.x. 
Harcourt, R., Bruine de Bruin, W., Dessai, S. and Taylor, A. (2020). ‘What adaptation stories are UK newspapers telling? A narrative analysis'. Environmental Communication 14 (8), pp. 1061-1078. https://doi.org/10.1080/17524032.2020.1767672.

Harré, R., Brockmeier, J. and Mühlhäusler, P. (1999). Greenspeak: a study of environmental discourse. Thousand Oaks, CA, U.S.A.: SAGE Publications.

Hartz, R. and Steger, T. (2010). 'Heroes, villains and 'honourable merchants': narrative change in the German media discourse on corporate governance'. Organization 17 (6), pp. 767-785. https://doi .org/10.1177/1350508410372558.

Harvey, F. (21st September 2020). ‘World's richest $1 \%$ cause double $\mathrm{CO}_{2}$ emissions of poorest $50 \%$, says Oxfam'. The Guardian.

URL: http://www . theguardian. com/environment/2020/sep/21/worlds-riche st-1-cause-double-co2-emissions-of-poorest-50-says-oxfam.

Hébert, L. (27th January 2019). 'Algirdas Julien Greimas. Le modèle actantiel'. Signo - Théories Sémiotiques Appliquées.

URL: http://www.signosemio.com/greimas/modele-actantiel.asp.

Henriksson, E. (2011). 'Indirect environmental action — Four stories of young adults, the hindrances they encountered and their driving-forces'. Master's thesis. Uppsala, Sweden: Swedish University of Agricultural Sciences.

URL: http://urn.kb.se/resolve?urn=urn:nbn: se: slu :epsilon-s-382.

Heuguet, G. (2020). 'Vues vérifiées, écoute évacuée: la valorisation publicitaire de la musique sur YouTube'. ticEsociété 14 (1-2), pp. 95-129. https://doi.org/10.4000/ticetsociete.4782.

Holland, M. (2017). 'How YouTube developed into a successful platform for user-generated content'. In: Young and creative: digital technologies empowering children in everyday life. Ed. by I. Eleá and L. Mikos. The International Clearinghouse on Children, Youth \& Media. Gothenburg, Sweden: Nordicom, University of Gothenburg, pp. 53-64.

Hwang, K. and Zhang, Q. (2018). 'Influence of parasocial relationship between digital celebrities and their followers on followers' purchase and electronic word-of-mouth intentions, and persuasion knowledge'. Computers in Human Behaviour 87, pp. 155-173. https : //doi .org/10.1016/j . chb.2018.05.029.

Jackson, T. (2009). Prosperity without growth: economics for a finite planet. London, U.K.: Earthscan.

Jalenques-Vigouroux, B. (2006). ‘Dire l'environnement: le métarécit environnemental en question'. Thèse de doctorat. Paris, France: Université Paris-Sorbonne (Paris IV).

Kelly, R. P., Cooley, S. R. and Klinger, T. (2014). ‘Narratives can motivate environmental action: the Whiskey Creek ocean acidification story'. Ambio 43 (5), pp. 592-599. https://doi.org/10.1007/s13280-013-0442-2.

Kleiche-Dray, M. and Waast, R. (2016). 'Indigenous knowledge in Mexico: between environmentalism and rural development'. In: Environmental governance in Latin America. Ed. by F. De Castro, B. Hogenboom and M. Baud. London, U.K.: Palgrave Macmillan. https://doi .org/10.1007/978-1-137-50572-9_4.

Koven, M. and Simões Marques, I. (2015). ‘Performing and evaluating (non)modernities of Portuguese migrant figures on YouTube: the case of Antonio de Carglouch'. Language in Society 44 (2), pp. 213-242. https://doi.org/10.1017/s0047404515000056. 
Ladhari, R., Massa, E. and Skandrani, H. (2020). 'YouTube vloggers' popularity and influence: the roles of homophily, emotional attachment, and expertise'. Journal of Retailing and Consumer Services 54, 102027. https://doi.org/10.1016/j.jretconser. 2019.102027.

Lahouati, M., De Coucy, A., Sarlangue, J. and Cazanave, C. (2020). 'Spread of vaccine hesitancy in France: what about YouTube ${ }^{\mathrm{TM}}$ ' Vaccine 38 (36), pp. 5779-5782. https://doi.org/10.1016/j.vaccine.2020.07.002.

León, B. and Bourk, M., eds. (2018). Communicating science and technology through online video: researching a new media phenomenon. London, U.K.: Routledge.

Luedecke, G. and Boykoff, M. T. (2017). 'Environment and the media'. In: The international encyclopedia of geography. Ed. by D. Richardson, N. Castree, M. F. Goodchild, A. Kobayashi, W. Liu and R. A. Marston. John Wiley \& Sons. https://doi.org/10.1002/9781118786352.wbieg0464. URL: https://science policy.colorado.edu/admin/publication_files/2017.04.pdf.

Lybecker, D. L., McBeth, M. K., Husmann, M. A. and Pelikan, N. (2015). ‘Do new media support new policy narratives? The social construction of the U.S.-Mexico border on YouTube'. Policy E Internet 7 (4), pp. 497-525. https://doi.org/10.1002/poi3.94.

Pazos, A. (2006). 'Recensión crítica: Philippe Descola, Par-delà nature et culture'. Revista de Antropología Iberoamericana 1 (1), pp. 186-194. URL: http: //www.redalyc .org/articulo.oa?id=62310113.

Propp, V. (1928). Morfología del cuento. Buenos Aires, Argentina: Ediciones Akal.

Rahmil, D.-J. (7th June 2021). 'Classement: qui sont les 10 plus gros youtubeurs français?' $L^{\prime} A D N$.

URL: https://www. ladn.eu/media-mutants/tv-et-nouvelles-images/classe ment-plus-gros-youtubeurs-francais-meilleurs-videastes/.

Rutherford, P. (1999). 'Ecological modernisation and environmental risk: Foucault and recent social theory'. In: Discourses of the environment. Ed. by É. Darier. Oxford, U.K.: Blackwell Publishers.

Santillán Vera, M. and de la Vega Navarro, A. (2019). 'Do the rich pollute more? Mexican household consumption by income level and $\mathrm{CO}_{2}$ emissions'. International Journal of Energy Sector Management 13 (3), pp. 694-712. https://doi.org/10.1108/IJESM-07-2018-0016.

Schlosberg, D. and Collins, L. B. (2014). 'From environmental to climate justice: climate change and the discourse of environmental justice'. WIREs Climate Change 5 (3), pp. 359-374. https : //doi .org/10.1002/wcc. 275.

Taylor, D. E. (2000). 'The rise of the environmental justice paradigm: injustice framing and the social construction of environmental discourses'. American Behavioral Scientist 43 (4), pp. 508-580. https://doi.org/10.1177/0002764200043004003.

Villagómez Ornelas, P. (2019). Rural poverty in Mexico: prevalence and challenges. Mexico City, Mexico: National Council for the Evaluation of Social Development Policy.

Welbourne, D. J. and Grant, W. J. (2016). 'Science communication on YouTube: factors that affect channel and video popularity'. Public Understanding of Science 25 (6), pp. 706-718. https://doi.org/10.1177/0963662515572068.

Wheeler, L. K. (2004). Freytag's pyramid. Linn Benton Community College. URL: http://cf.linnbenton.edu/artcom/performing_arts/stoned/upload/C lassical\%20Plot\%20Structure.pdf. 
Wiedmann, T., Lenzen, M., Keyßer, L. T. and Steinberger, J. K. (2020). 'Scientists' warning on affluence'. Nature Communications 11 (3107).

https://doi .org/10.1038/s41467-020-16941-y.

Authors

Cecilia Lartigue es currently a Ph.D. student at the University of Toulouse II Jean Jaurès. She has longtime experience in environmental communication, particularly in water communication, and has also worked in several environmental management projects. E-mail: cecilia.lartigue@gmail.com.

Dr. Guillaume Carbou is currently an Assistant Professor at the University of Bordeaux (France). His work takes place in the field of communication studies and his current research topics are about public controversies on environnemental issues. E-mail: guillaume.carbou@gmail.com.

Dr. Muriel Lefebvre is professor at the University of Toulouse II Jean Jaurès. Her researches take place in the field of communication studies, and are related to culture and scientific communication. E-mail: muriel.lefebvre@univ-tlse2.fr.

\section{How to cite}

Lartigue, C., Carbou, G. and Lefebvre, M. (2021). 'Individual solutions to collective problems: the paradoxical treatment of environmental issues on Mexican and French YouTubers' videos'. JCOM 20 (07), A07. https://doi.org/10.22323/2.20070207. 